\title{
Pengaruh Metode Sulfonasi dan Penambahan Pengisi pada Membran Direct Metanol Fuel Cell
}

\author{
Effect of Sulfonation Method and Addition of Filler on Direct \\ Methanol Fuel Cell
}

\author{
Muhammad Fahmi Hakim ${ }^{*}$ dan Tutuk Djoko Kusworo ${ }^{2}$ \\ ${ }^{1}$ Fakultas Teknik, Universitas Singaperbangsa Karawang, Jalan H.S. Ronggowaluyo Telukjambe Timur, \\ Kabupaten Karawang 41361 - Jawa Barat \\ ${ }^{2}$ Program Studi Teknik Kimia, Fakultas Teknik, Universitas Diponegoro Semarang, Jl. Prof. H. Soedarto, SH. \\ Tembalang Semarang 50239 \\ *e-mail: muhammad.fahmi@ft.unsika.ac.id
}

\begin{abstract}
ABSTRAK
Penggunaan polieter-eter keton (PEEK) sebagai membran pengganti

Histori Artikel:

Diajukan:

$16 / 09 / 2018$

Diterima:

$31 / 10 / 2018$

Diterbitkan:

$17 / 11 / 2018$ nafion pada aplikasi direct methanol fuel cell (DMFC) menjadi penelitian yang terus dikembangkan, Penyempurnaan PEEK menuju karakteristik nafion juga terus dilakukan dengan berbagai metode, baik itu dengan penambahan pengisi maupun pengembangan metode baru dalam proses pembuatan membran PEEK. Methanol crossover dan rendahnya nilai konduktifitas menjadi salah satu kelemahan membran PEEK yang masih perlu di selesaikan dengan cara yang solutif. Tujuan percobaan ini adalah melakukan pengembangan metode pembuatan membran serta menambahkan bahan pengisi untuk memperbaiki karakteristik membran PEEK. Dengan metode A yaitu penambahan pengisi siklodekstrin $10 \%$ sebelum proses sulfonasi, metode B yaitu penambahan pengisi siklodekstrin dan silika dilakukan setelah proses sulfonasi pada suhu dan waktu tetap 700C selama 4 jam, hasil karakteristik terbaik diantara dua metode tersebut kemudian ditambahakan pengisi silika untuk meningkatkan sifat hidrofilik membran. Hasil percobaan menunjukkan hasil terbaik pada membran sPEEK-siklodekstrin-silika $10 \%$ dengan metode $\mathrm{A}$, penambahan pengisi dilakukan sebelum sulfonasi, dengan nilai swelling degree $140 \%$ dan hasil analisa FTIR gugus sulfonat pada membran sPEEK-siklodekstrin-silika $10 \%$ yaitu terdapat pada rentang panjang gelombang 1153-1155 cm-1 dan $1217 \mathrm{~cm}-1$ (vibrasi stretching simmetrik dan assimetrik $\mathrm{O}=\mathrm{S}=0$ ).
\end{abstract}

Kata kunci: dmfc, sPEEK, siklodekstrin, silika, Swelling degree, FTIR

\begin{abstract}
The use of polyether-ether ketone (PEEK) as a replacement membran for nafion in direct methanol fuel cell (DMFC) applications is a research that continues to be developed. The improvement of PEEK towards the characteristics of nafion also continues to be carried out by various methods, both by adding fillers and developing new methods in the process. PEEK membran manufacture. Methanol crossover and low conductivity values are one of the weaknesses of PEEK membrane that still needs to be solved in a solutive way. The purpose of this experiment was to develop methods for making membrans and add fillers to improve the characteristics of PEEK membrans. With method A, the addition of $10 \%$ cyclodextrin filler before the sulfonation process, method B is the addition of cyclodextrin fillers after sulfonation at 700C for fixed hours and temperature for 4 hours, the best characteristics between the two methods are then added to the silica filler to improve the hydrophilic properties of the membran. The experimental results showed the best results on the $10 \%$ SPEEK-silica-cyclodextrinine membrane with method A, the addition of fillers was carried out before sulfonation, with the swelling degree $140 \%$ and the results of FTIR sulfonate group analysis on the SPEEK-cyclodextrin-silica membran 10\% that is found in the wavelength range 1153-1155 $\mathrm{cm}-1$ and $1217 \mathrm{~cm}-1$ (symmetric and assimetric stretching vibration $\mathrm{O}=\mathrm{S}=0$ ).
\end{abstract}

Keywords: DMFC, SPEEK, Cyclodextrin, Silica, Swelling degree, FTIR 


\section{PENDAHULUAN}

Pengembangan material membran DMFC saat ini terfokus pada peningkatan nilai konduktifitas dan menanggulangi terjadinya methanol crossover, nafion merupakan membran komersil yang saat ini menjadi acuan secara karakteristik untuk diaplikasikan pada DMFC. Kelemahan utama dari membran nafion adalah harganya yang terlalu tinggi sehingga menghambat komersialisasi dan penerapan di segala bidang yang membutuhkan pengembangan energi baru terbarukan khususnya fuel cell (Wang et al., 2018). Polieter-eter ketone adalah material membran yang dikembangkan untuk menggantikan nafion pada DMFC, sifat mekanik dan kimia yang dimiliki PEEK sesuai dengan karakteristik membran pada DMFC, namun pada pengembangannya membran PEEK masih memiliki kekurangan yaitu, terjadinya methanol crossover dan nilai konduktifitas proton yang rendah (Kusworo, Hakim, \& Hadiyanto, 2017).

Modifikasi membran PEEK dilakukan untuk meningkatkan nilai konduktifitas proton dan mengurangi terjadinya methanol crossover. Modifikasi yang dilakukan oleh para peneliti umumnya menambahkan bahan pengisi untuk memperbaiki karakteristik membran PEEK.

(Ismail, Othman, \& Mustafa, 2009) dalam penelitiannya melakukan modifikasi sPEEK dengan penambahan bahan isian tungstosilicic acid pada komposit silicaaluminium oxide dengan variasi muatan 30-70 wt\% tungstosilicic acid dan 25-75 wt\% silika oksida. Hasil yang diperoleh terkhusus untuk analisa nilai konduktifitas adalah $60,99 \times 10$ $3 \mathrm{~S} / \mathrm{cm}$. Semakin tinggi muatan silika oksida dan tungsticililic acid yang ditambahkan maka nilai konduktifitas semakin tinggi. Untuk uji permeabilitas metanol juga menunjukkan hasil yang semakin tinggi seiring dengan penambahan bahan isian, Sedangkan standar membran dalam aplikasi DMFC adalah memiliki nilai konduktifitas yang tinggi dan nilai permeabilitas metanol yang rendah.

(Mat \& Liong, 2009) dalam penelitiannya melakukan modifikasi membran kitosan - polivinil alkohol dan kalsium oksida dan memperoleh hasil, menurunnya permeabilitas metanol tetapi nilai konduktifitas proton juga

ikut menurun. (Dhuhita, A dan Arti, 2010) dalam penelitiannya melakukan modifikasi membran sPEEK-cSMMs dan memperoleh hasil, nilai permeabilitas metanol dan kapasitas penukar ion menurun dengan meningkatnya konsentrasi pengisi dalam membran dan daya hantar ionik masih rendah.

Penelitian yang telah dilakukan hingga saat ini untuk mengganti nafion dengan PEEK masih belum memenuhi karakteristik konduktifitas proton yang tinggi dan permeabilitas metanol sekecil mungkin. Sehingga masih perlu dilakukan modifikasi membran PEEK (Gwak, Kim, Lee, \& Ju, 2018). Percobaan ini bertujuan untuk melakukan pengembangan metode pembuatan membran serta menambahkan bahan pengisi untuk memperbaiki karakteristik membran PEEK. Dengan metode A yaitu penambahan pengisi siklodekstrin $10 \%$ sebelum proses sulfonasi, metode $B$ yaitu penambahan pengisi siklodekstrin dan silika dilakukan setelah proses sulfonasi pada suhu dan waktu tetap 700C selama 4 jam.

Siklodekstrin dipilih untuk menjadi pengisi pada membran sPEEK dikarenakan dapat membentuk senyawa kompleks inklusi sehingga dapat meningkatkan kelarutan senyawa, mengikat senyawa volatil, melindungi senyawa yang labil, mengurangi efek toksisitas suatu senyawa dan memperbaiki tekstur (Noor \& Hartoto, 2011). Siklodekstrin merupakan suatu material yang memiliki potensi digunakan sebagai pengisi pada membran sPEEK dengan harapan dapat meningkatkan nilai konduktivitas proton dikarenakan sifat siklodekstrin yang merupakan konduktif polimer dengan struktur berbentuk toroid (kerucut terpotong), permukaan luar bersifat hidrofilik dan permukaan dalam yang bersifat hidrofobik sehingga mampu melakukan penyerapan air secara stabil (Peng et al., 2016).

Variasi metode sulfonasi yang akan dilakukan pada penelitian ini mengingat pentingnya sulfonasi pada proses pembuatan membran PEEK. Proses sulfonasi dapat menentukan jumlah gugus sulfonat yang berada pada membran. Banyaknya gugus sulfonat ( $\mathrm{SO} 3 \mathrm{H}$ ) yang terikat pada polimer saat terjadi proses sulfonasi akan menyediakan media transfer proton yang lebih baik (Handayani, Dewi, Hardy, Christiani, \& Kurniawan, 2012).

\section{METODE PENELITIAN}

Bahan utama penelitian ini yaitu PEEK dikeringkan dalam oven selama 12 jam untuk menghilangkan kandungan air yang diakibatkan oleh proses pengemasan maupun pengiriman. Pada percobaan ini terdapat dua 
metode pembuatan komposit membran, Metode A, PEEK kering ditimbang 5 gram dan dilarutkan kedalam asam sulfat bersamaan dengan penambahan pengisi siklodekstrin $10 \%$ / siklodekstrin-silika 10\% dengan pengadukan pada suhu $70 \mathrm{oC}$ selama 4 jam. Metode $B$, penambahan pengisi dilakukan setelah selesai proses sulfonasi. setelah kedua metode dilakukan selanjutnya padatan sPEEK yang terbentuk dicuci dengan aquades hingga mencapai PH netral. Padatan PEEK kemudian di keringkan pada suhu ruang 12 jam, selanjutnya dipanaskan dalam oven pada suhu 50oC selama 5 jam.

Pelarutan sPEEK kering dilakukan menggunakan pelarut Dimetil acetamid (DMAc), pada metode B sejumlah pengisi yaitu siklodekstrin/ silika ditambahkan di tahap ini. Pengadukan dilakukan selama 5 jam hingga sPEEK kering larut sempurna. Pencetakan membran menggunakan cawan petri dengan ketebalan membran $80 \mu \mathrm{m}$, selanjut dikeringkan dalam oven selama 48 jam pada suhu 500 .

Swelling Degree membran dianalisa dengan mengukur panjang membran sebelum membran direndam kedalam air selama dua hari dua malam, kemudian membran dikeringkan dalam oven pada suhu 120oC selama 2 jam dan diukur kembali panjang membran, secara matematis nilai swelling degree membran dapat dihitung menggunakan rumus berikut:

$$
S D=\quad \frac{L w e t-L d r y}{L d r y} \mathrm{X} 100 \%
$$

di mana SD, Lwet dan Ldry merepresentasikan swelling degree, dalam persen berat (wt.\%), dan panjang membran basah, kering.

\section{HASIL DAN PEMBAHASAN}

\section{Swelling Degree}

Swelling degree adalah derajat pengembangan yang berkaitan dengan sifat fisik atau mekanik membran serta kemampuan membran dalam menyerap dan menyimpan air. Keberadaan air dapat memfasilitasi transportasi proton. Penambahan bahan pengisi siklodekstrin-silika dan variasi metode sulfonasi menghasilkan nilai swelling degree sebagaimana yang tersaji pada Tabel 1 . Berikut ini
Tabel 1. Nilai Swelling Degree Tiap Sampel

\begin{tabular}{lc}
\hline \multicolumn{1}{c}{ Sampel } & $\begin{array}{c}\text { Swelling Degree } \\
(\%)\end{array}$ \\
\hline $\begin{array}{l}\text { sPEEK-siklodekstrin } \\
\text { 10\% (metode A) }\end{array}$ & 35 \\
$\begin{array}{l}\text { Siklodekstrin 10\% } \\
\text { (metode B) }\end{array}$ & 42 \\
sPEEK-siklodekstrin- & \\
silika 10\% & 140 \\
\hline
\end{tabular}

sPEEK-siklodekstrin-silika

memiliki nilai swelling degree tertinggi yaitu $140 \%$, hasil ini menunjukan peningkatan yang baik untuk membran dalam aplikasi DMFC karna semakin tinggi kemampuan membran menyerap air maka nilai konduktifitas membran juga semakin besar.

Sifat asam heteropoli yang dapat larut dalam air menunjukkan kemampuan hidofilik yang tinggi artinya penyerapan air dalam membran juga sangat tinggi. Hal ini dapat mengakibatkan menurunnya stabilitas mekanik membran sehingga membran menjadi mudah robek dan nyaris terlarut dalam air.

\section{Fourier Transform Infra Red (FTIR)}

Untuk mengetahui blending siklodekstrin yang telah dilakukan pada penelitian ini terjadi dengan baik, maka dilakukanlah analisa FTIR terhadap komposit membran sPEEK, sPEEK siklodekstrin 10\% (metode B), serta bahan pengisi siklodekstrin dengan hasil analisa seperti yang ditunjukkan pada Gambar 1. 


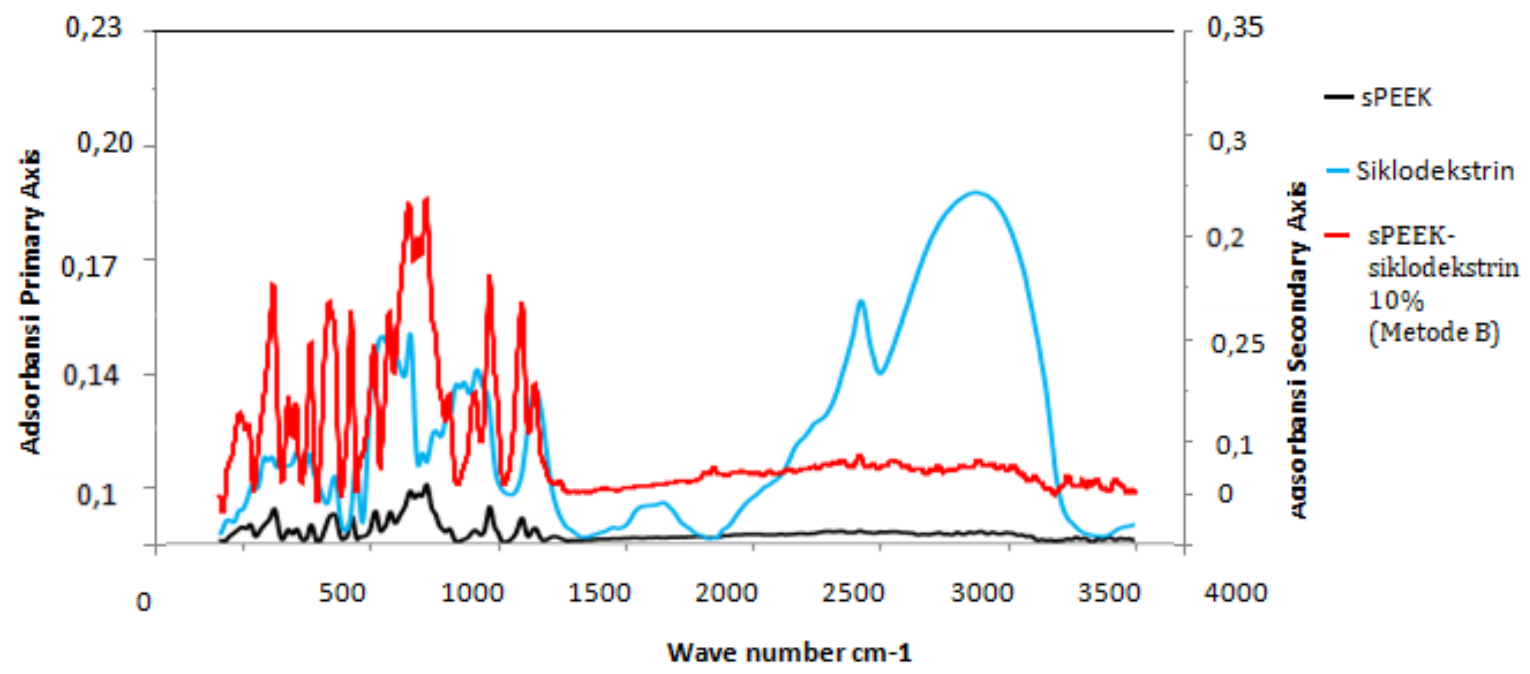

Gambar 1. Grafik Spektrum FTIR komposit membran sPEEK, sPEEK-siklodekstrin 10\% (tanpa sulfonasi), dan Siklodekstrin.

Pengujian FTIR menghasilkan grafik adsorbansi sampel pada suatu nilai panjang gelombang. Berdasarkan Gambar 1. hasil analisa FTIR terhadap sPEEK, siklodekstrin dan sPEEK-siklodekstrin 10\% (metode B), yang dimaksudkan untuk mengetahui penambahan siklodekstrin $10 \%$ pada sPEEK telah berhasil masuk kedalam membran SPEEK, hal tersebut dibuktikan dengan Gambar 1. dimana tren berwarna biru yang mewakili siklodekstrin dengan puncak adsorbansi 0,006-0,19 sepenuhnya berada didalam tren merah yang mewakili sPEEK-siklodekstrin 10\% (metode B) dengan puncak adsorbansi 0,02-0,27 dan berada diatas tren berwarna hitam yang mewakili sPEEK dengan puncak adsorbansi 0,004-0,11, dari rentang panjang gelombang $500-4000 \mathrm{~cm}-1$.

Untuk mengetahui pengaruh sulfonasi pada proses pembuatan komposit membran, maka dilakukanlah analisa FTIR terhadap sPEEK-siklodekstrin 10\% (metode B) dan sPEEK-siklodekstrin 10\% (metode A) dengan hasil analisa seperti yang ditunjukkan pada Gambar 2.

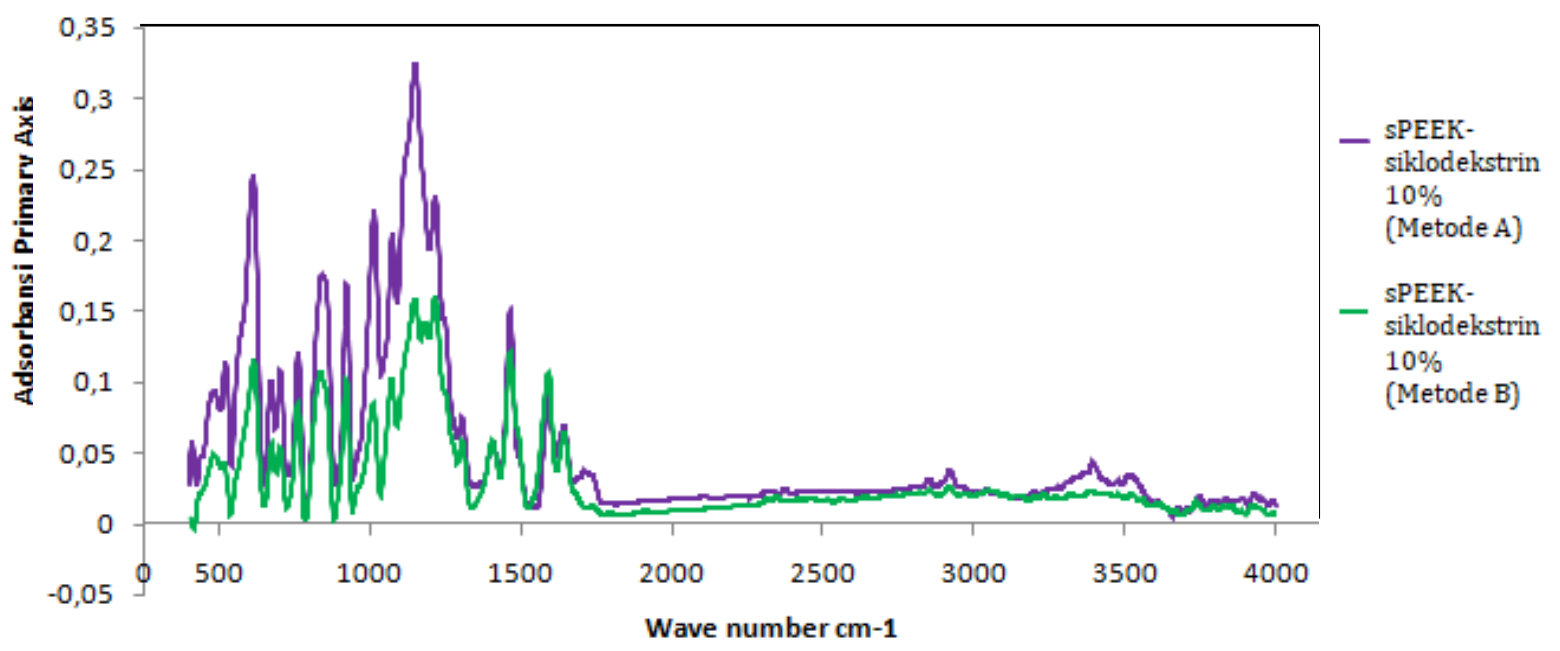

Gambar 2. Grafik Spektrum FTIR komposit membran sPEEK-siklodekstrin 10\% (metode B) dan sPEEKsiklodekstrin $10 \%$ (metode A).

Secara kualitatif gugus sulfonat yang berada dalam membran sPEEK dapat dilihat dari hasil analisa FTIR, seperti yang ditunjukkan pada Gambar 2. gugus sulfonat pada membran sPEEK-siklodekstrin 10\% (metode A) terdapat pada panjang gelombang 
1153-1155 $\mathrm{cm}^{-1}$ dan $1217 \mathrm{~cm}^{-1}$ (vibrasi stretching simmetrik dan assimetrik $\mathrm{O}=\mathrm{S}=0$ ) (Yee, Zhang, \& Ladewig, 2013). Sedangkan pada sPEEK-siklodekstrin-silika $10 \%$ (metode B) terjadi penurunan bilangan gelombang menjadi $1076 \mathrm{~cm}^{-1}$ dan $1188 \mathrm{~cm}^{-1}$. Hal ini dikarenakan pada sPEEK-siklodekstrin 10\% (metode A) adanya ikatan gugus sulfonat (SO3) dengan $\mathrm{C}$ pada ikatan hidrokarbon siklodekstrin sehingga menaikkan serapan panjang gelombang gugus sulfonat.

Sedangkan pada sPEEK-siklodekstrin 10\% (metode B), pencampuran sPEEK dengan pelarut DMAc bersamaan dengan penambahan siklodekstrin menyebabkan terjadinya interaksi yang kuat antara polimer sPEEK dengan pelarut DMAc yang ditandai dengan lebih kecilnya suhu transisi glass pada membran sPEEK $\left(265^{\circ} \mathrm{C}\right)$ dibanding dengan sPEEK-siklodekstrin $10 \%$ (metode A) yaitu $218^{\circ} \mathrm{C}$.

Untuk mengetahui pengaruh blending silika terhadap membran sPEEK- siklodekstrin, dilakukan analisa FTIR terhadap membran sPEEK-siklodekstrin (metode A) 10\% dan sPEEK-siklodekstrin-silika 10\% menunjukkan hasil analisa seperti yang ditampilkan pada Gambar 3.

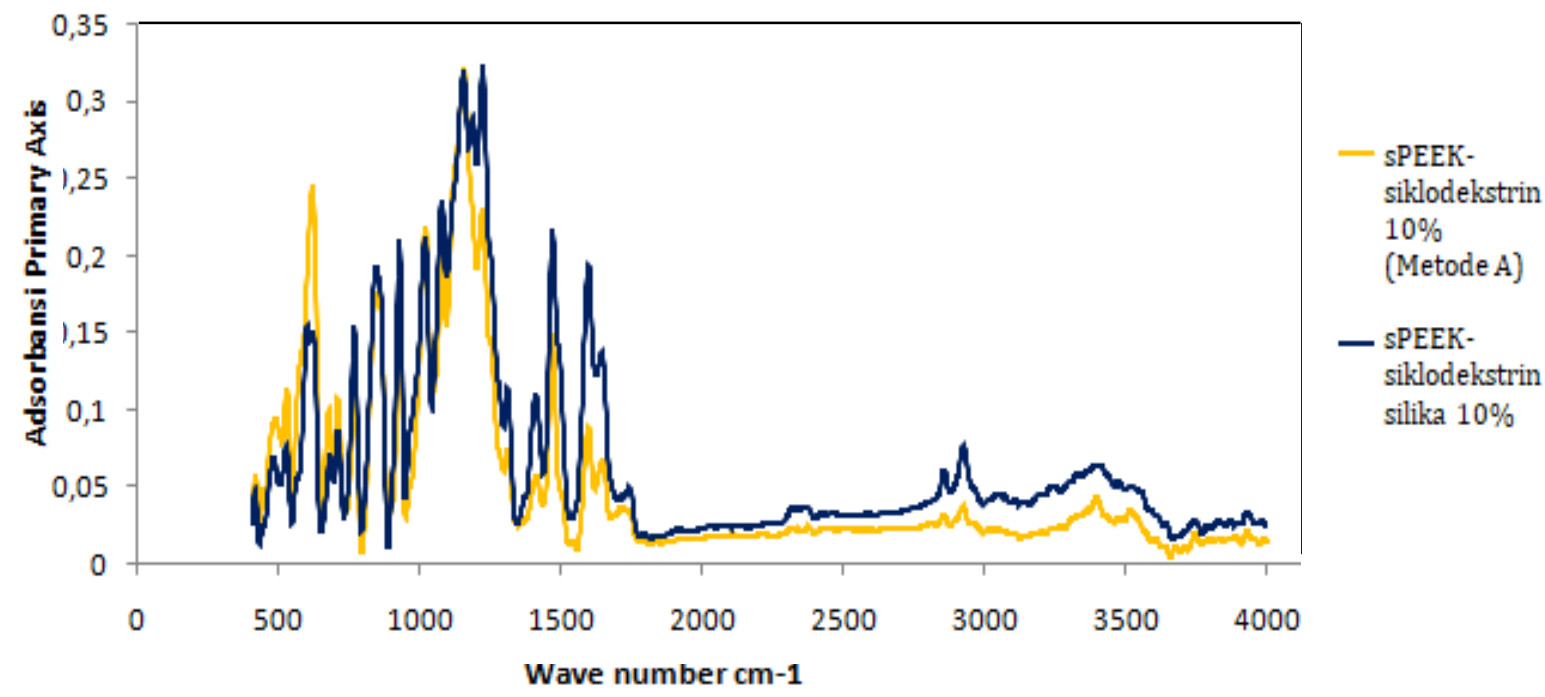

Gambar 3. Grafik Spektrum FTIR komposit membran sPEEK-siklodekstrin 10\% (Metode B) dan sPEEKsiklodekstrin-silika 10\% (Metode A).

Berdasarkan Gambar 3. dilakukan pengamatan gugus fungsional pada silika dalam sPEEK-siklodekstrin-silika 10\%. Hasil yang diperoleh menunnjukkan bahwa puncak utama yang berkaitan dengan gugus fungsi pada silika adalah pada bilangan gelombang $3444,6 \mathrm{~cm}^{-1}$ yang merupakan gugus $-\mathrm{OH}$ (gugus hidroksil) yang menunjukkan adanya gugus hidroksil dari molekul air yang terhidrasi. Selain itu puncak bilangan gelombang 1095,5 $\mathrm{cm}^{-1}$ menunjukkan adanya gugus fungsi Si-O-Si. Adanya gugus fungsi Si-OSi diperkuat dengan adanya puncak bilangan gelombang 470,6 cm-1 yaitu ikatan Si-O.

Gugus sulfonat yang berada dalam membran sPEEK dapat dilihat dari hasil analisa FTIR, seperti yang ditunjukkan pada Gambar 3. gugus sulfonat pada membran sPEEK-siklodekstrin 10\% (dengan sulfonasi) berada pada panjang gelombang yang hampir sama dengan membran sPEEK-siklodekstrinsilika $10 \%$, yaitu terdapat pada rentang panjang gelombang 1153-1155 $\mathrm{cm}^{-1}$ dan 1217 $\mathrm{cm}^{-1}$ (vibrasi stretching simmetrik dan assimetrik $\mathrm{O}=\mathrm{S}=0$ ),

Beberapa hal penting yang membedakan antara hasil analisa FTIR membran sPEEKsiklodekstrin 10\% (metode A) dan sPEEKsiklodekstrin-silika $10 \%$ adalah puncak serapan gugus sulfonat pada membran sPEEKsiklodekstrin-silika yang lebih tinggi dibandingkan dengan membran sPEEKsiklodekstrin 10\% (metode A) yaitu 0,33, terutama pada puncak gelombang $3300 \mathrm{~cm}-1$ $3700 \mathrm{~cm}^{-1}$ yaitu daerah teridentifikasi gugus hidroksil $-\mathrm{OH}$ yang juga mengintepretasikan daya serap membran sPEEK-siklodekstrinsilika yang lebih tinggi (Prapainainar et al., 2018), hal ini disebabkan oleh ikatan $-\mathrm{OH}$ yang berasal dari $\mathrm{O}$ pada silika dan $\mathrm{H}$ dari 
hidrokarbon sPEEK, semakin tinggi daya serap membran maka akan memudahkan transport proton pada membran DMFC (Handayani \& Dewi, 2010).

\section{KESIMPULAN}

sPEEK dengan komposisi penambahan siklodekstrin-silika $10 \%$ memberikan nilai swelling degree terbaik. Metode A yaitu pencampuran pengisi dilakukan sebelum proses sulfonasi meningkatkan jumlah gugus sulfonat dalam membran, terlihat dari hasil analisa gugus sulfonat pada membran sPEEKsiklodekstrin-silika $10 \%$ yaitu terdapat pada rentang panjang gelombang 1153-1155 $\mathrm{cm}^{-1}$ dan $1217 \mathrm{~cm}^{-1}$ (vibrasi stretching simmetrik dan assimetrik $\mathrm{O}=\mathrm{S}=0$ ).

\section{DAFTAR PUSTAKA}

Dhuhita, A. dan Arti, D. K. (2010). Untuk Aplikasi Direct Methanol Fuel Cell ( Dmfc ) Diajukan untuk memenuhi salah satu persyaratan tugas akhir guna memperoleh gelar Sarjana Teknik Oleh: Halaman Pengesahan Skripsi.

Gwak, G. Kim, D. Lee, S. \& Ju, H. (2018). Studies of the methanol crossover and cell performance behaviors of high temperature-direct methanol fuel cells (HT-DMFCs). International Journal of Hydrogen Energy, 43(30), 13999-14011. https://doi.org/10.1016/j.ijhydene.2017.1 1.029

Handayani, S. Dewi, E. L. Hardy, J. Christiani, L. \& Kurniawan. (2012). Influence of Composite Electrolyte Membrane for Proton Exchange Membrane Fuel Cells. Procedia Chemistry, 4, 123-130. https://doi.org/10.1016/j.proche.2012.06. 018

Handayani, S. \& Dewi, E. L. (2010). The Effect Of Membrane Thickness Of Hydrocarbon Composite Polymer To, 31-34.

Ismail, A. F. Othman, N. H. \& Mustafa, A. (2009). Sulfonated polyether ether ketone composite membrane using tungstosilicic acid supported on silica-aluminium oxide for direct methanol fuel cell (DMFC). Journal of Membrane Science, 329(1-2), 18-29.

https://doi.org/10.1016/j.memsci.2008.11 .052

Kusworo, T. D. Hakim, M. F. \& Hadiyanto, H. (2017). Enhancement of Hybrid SPEEK
Based Polymer-Cyclodextrin-Silica Inorganic Membrane for Direct Methanol Fuel Cell Application. International Journal of Renewable Energy Development, 6(2),165.

https://doi.org/10.14710/ijred.6.2.165170

Mat, N. C. \& Liong, A. (2009). Chitosan-poly (vinyl alcohol) and calcium oxide composite membrane for direct methanol fuel cell applications. Engineering Letters.

Noor, E. \& Hartoto, D. L. (2011). Produksi Siklodekstrin Dari Pati Garut Menggunakan Berbagai Kombinasi Enzim [Production of Cyclodextrin from Arrowroot Starch by Using the Combination Enzymes]. Hasil Penelitian J. Teknol. Dan Industri Pangan.

Peng, K. Chen, C. Pan, W. Liu, W. Wang, Z. \& Zhu, L. (2016). Preparation and properties of $\beta$-cyclodextrin $/ 4,4^{\prime}$-diphenylmethane diisocyanate/polyethylene glycol $(\beta$ CD/MDI/PEG) crosslinking copolymers as polymeric solid-solid phase change materials. Solar Energy Materials and Solar Cells. https://doi.org/10.1016/j.solmat.2015.10. 031

Prapainainar, P. Maliwan, S. Sarakham, K. Du, Z. Prapainainar, C. Holmes, S. M. \& Kongkachuichay, P. (2018). Homogeneous polymer/filler composite membrane by spraying method for enhanced direct methanol fuel cell performance. International Journal of Hydrogen Energy, 43(31), 14675-14690. https://doi.org/10.1016/j.ijhydene.2018.0 5.173

Wang, M. Chen, M. Yang, Z. Wang, Y. Wang, Y. Liu, G. Wang, X. (2018). A study on fuel additive of methanol for room temperature direct methanol fuel cells. Energy Conversion and Management, 168(May), 270-275. https://doi.org/10.1016/j.enconman.2018. 05.006

Yee, R. Zhang, K. \& Ladewig, B. (2013). The Effects of Sulfonated Poly(ether ether ketone) Ion Exchange Preparation Conditions on Membrane Properties. Membranes, 3(3), 182-195. https://doi.org/10.3390/membranes3030 182 